\title{
Food webs in forest and pasture streams in the Waikato region, New Zealand: a study based on analyses of stable isotopes of carbon and nitrogen, and fish gut contents
}

\section{BRENDAN J. HICKS}

Department of Biological Sciences

University of Waikato

Private Bag 3105

Hamilton, New Zealand

\begin{abstract}
Stable isotopes of carbon (C) and nitrogen $(\mathrm{N})$ were studied in 11 stream communities in the Waikato region of New Zealand. From comparisons of mean $\delta^{13} \mathrm{C}$ and $\delta^{15} \mathrm{~N}$ values, food webs in the shaded, forest streams were clearly based on allochthonous material (conditioned leaf litter and terrestrial invertebrates). Autotrophs in forest streams were not a significant $\mathrm{C}$ source for the food webs. However, the $\mathrm{C}$ source of food webs in the unshaded pasture streams appeared to be a mixture of allochthonous and autochthonous material. Conditioned leaf litter appeared to contribute to the pasture stream food webs, and the $\delta^{13} \mathrm{C}$ and $\delta^{15} \mathrm{~N}$ of some samples of epilithic diatoms indicated their consumption by invertebrates in pasture streams. Fish ate a wide range of aquatic invertebrates; longfinned eels (Anguilla dieffenbachii) and banded kokopu (Galaxias fasciatus) also had a large proportion of terrestrial invertebrates in their diet. Filamentous green algae were found only at pasture sites, where they were sometimes abundant. The wide range of $\delta^{13} \mathrm{C}$ values of filamentous green algae $(-18.8$ to $-29.7 \%$ ) complicated understanding of their role in the stream food webs. The $\delta^{13} \mathrm{C}$ values of Cladophora were related to water velocity, with more ${ }^{13} \mathrm{C}$ enriched values in pools than in runs $(-23.2 \%$ in pools, mean velocity $0.12 \mathrm{~m} \mathrm{~s}^{-1} ;-28.1 \%$ in runs, mean velocity $0.24 \mathrm{~m} \mathrm{~s}^{-1}$ ). Crayfish and the gastropod mollusc Potamopyrgus appeared to be the only invertebrates to eat filamentous green algae.
\end{abstract}

\section{M97012}

Received 2 April 1997; accepted 13 October 1997
Keywords stable isotopes; carbon; nitrogen; invertebrates; fish; food webs; land use

\section{INTRODUCTION}

In the Waikato region of New Zealand, biomass of fish and eel production has been related to land use. Pasture streams had much greater fish biomass and eel production than forested streams (Hicks \& McCaughan 1997), and pasture streams also had the greater primary production (Quinn et al. 1997a). The aim of this project was to investigate the influence of land use on food webs in streams in the Waikato region. Food webs in streams begin with inputs of organic and inorganic carbon (C) and light, and food web components may include algae, leaf litter, non-predatory and predatory invertebrates, and fish (e.g., Rounick \& Winterbourn 1986). Catchment vegetation, especially in the riparian zone, has a major influence on food webs in streams, through both shading and litter inputs (e.g., Vannote et al. 1980; Cummins et al. 1989; Gregory et al. 1991).

Food webs were studied by tracing the fractionation of stable isotopes of $\mathrm{C}\left({ }^{12} \mathrm{C}\right.$ and $\left.{ }^{13} \mathrm{C}\right)$, and nitrogen $(\mathrm{N})\left({ }^{14} \mathrm{~N}\right.$ and $\left.{ }^{15} \mathrm{~N}\right)$, and by examining the gut contents of fish. The basis of the isotope technique is that enzymatic and diffusion processes discriminate against the heavier isotopes of both $\mathrm{C}$ and $\mathrm{N}$, resulting in a predictable change in isotopic ratio in the consumer compared to the source (Griffiths 1991). The use of both $\mathrm{C}$ and $\mathrm{N}$ isotopes together improves the resolution of food webs compared to analysis of $\mathrm{C}$ isotopes alone (Peterson \& Fry 1987; Fry 1991), and overcomes some of the criticisms recently aimed at isotope food-web analyses by France (1995a; 1996a,b,c).

\section{Isotopic ratios of carbon}

The importance of allochthonous $C$ compared to autochthonous $\mathrm{C}$ as a base for secondary production can theoretically be determined from the $\delta^{13} \mathrm{C}$ of 
the consumers. Allochthonous $\mathrm{C}$ derived from terrestrial plants with the $\mathrm{C}_{3}$ photosynthetic pathway generally has a $\delta^{13} \mathrm{C}$ value of -26 to $-29 \%$, c. $20 \%$ less than the $\delta^{13} \mathrm{C}$ value of atmospheric $\mathrm{CO}_{2}(-8 \%$; O'Leary 1988). Diffusion and photosynthesis discriminate against ${ }^{13} \mathrm{C}$, the heavier stable isotope of $\mathrm{C}$. In water, $\mathrm{HCO}_{3}{ }^{-}$can act as a $\mathrm{C}$ source. Since the $\delta^{13} \mathrm{C}$ of $\mathrm{HCO}_{3}^{-}$can be $9 \%$ more negative than dissolved $\mathrm{CO}_{2}$, photosynthesis using $\mathrm{HCO}_{3}{ }^{-}$can result in aquatic plant tissue that has $\delta^{13} \mathrm{C}$ values of c. $-35 \%$ (e.g., Rau 1980; Rounick \& Hicks 1985).

In practice, the $\delta^{13} \mathrm{C}$ values of terrestrial and aquatic is quite variable. Substrate limitation can overcome enzymatic discrimination, resulting in less negative $\delta^{13} \mathrm{C}$ values than expected. Carbon in in the leaves of terrestrial plants may vary seasonally in $\delta^{13} \mathrm{C}$ by $5 \%$ in response to stomatal closure at times of water stress (Walcroft et al. 1997). High irradiance can cause terrestrial leaves to be less negative in $\delta^{13} \mathrm{C}$ than leaves photosynthising at low irradiance; leaves in the upper canopy can be 3-4\%o less negative than leaves in the lower canopy (Ehleringer et al. 1986; Schlesser 1990, 1992).

Aquatic plants photosynthising in water also show seasonal variability in $\delta^{13} \mathrm{C}$ (Boon \& Bunn 1994). In lake phytoplankton, high rates of photosynthesis lead to substrate limitation and $\delta^{13} \mathrm{C}$ values close to $0 \%$ (McCabe 1985). Despite this variability, aquatic plants often have different values of $\delta^{13} \mathrm{C}$ than land plants (O'Leary 1988), which enables determination of whether a food web is principally based on land plants or in-stream primary production (e.g., Rounick et al. 1982; Winterbourn et al. 1984; Rounick \& Hicks 1985). Where isotopic signatures of $\mathrm{C}$ sources do not follow predictions, the results may still usefully indicate testable hypotheses concerning ecosystem function.

The $\mathrm{C}$ ratio of each consumer should reflect its assimilated $\mathrm{C}$, with an enrichment in ${ }^{13} \mathrm{C}$ caused by the assimilatory and respiratory processes that use ${ }^{12} \mathrm{C}$ preferentially. The $\delta^{13} \mathrm{C}$ of the consumer can be $0-1 \%$ less negative than its food (Peterson \& Fry 1987). White muscle of rainbow trout (Oncorhynchus mykiss) aged 0-2 years and fed on trout pellets was $0.9-1.7 \%$ less negative than their food; enrichment declined with age and size (Rounick \& Hicks 1985). A similar decline of ${ }^{13} \mathrm{C}$ enrichment with increasing size was observed in brook char (Salvelinus fontinalis, Peterson \& Howarth 1987).

\section{Isotopic ratios of nitrogen}

The ratio of ${ }^{15} \mathrm{~N} /{ }^{14} \mathrm{~N}$ in air is relatively invariant (Mariotti 1983), and is the defined zero point. Leaves of terrestrial plants may range in $\delta^{15} \mathrm{~N}$ from -8 to $+3 \%$, and where aquatic plants have different values to those of terrestrial plants that might contribute litter to a stream, $\mathrm{N}$ isotopes may function as source markers for tracing the autochthonous or allochthonous origin of $\mathrm{N}$ in food webs, augmenting information from the ratio of ${ }^{13} \mathrm{C} /{ }^{12} \mathrm{C}$ (Peterson \& Fry 1987; France 1995b). Nitrogen fixation also affects the $\delta^{15} \mathrm{~N}$ of $\mathrm{N}$ sources, resulting in organic $\mathrm{N}$ that is $\delta^{15} \mathrm{~N} 0.6-4.1 \%$ more negative than the $\mathrm{N}$ source. Values in plant tissues reflect their $\mathrm{N}$ source (Handley \& Raven 1992; France 1995b).

Nitrogen in most parts of the biosphere has $\delta^{15} \mathrm{~N}$ values ranging from -10 to $+10 \%$, primarily because the $\mathrm{N}$ uptake by plants and microbes is limited by supply rather than by enzymatic uptake (Peterson \& Fry 1987). However, subsequent fractionation is greater for ${ }^{15} \mathrm{~N}$ than for ${ }^{13} \mathrm{C}$, frequently resulting in a c. $3 \%$ increase in $\delta^{15} \mathrm{~N}$ between trophic levels (Peterson \& Fry 1987; Handley \& Raven 1992).

\section{STUDY AREAS}

Study sites in the Waikato region were located on streams draining native forest (three sites), exotic forests of Pinus radiata (four sites), and pasture lands (four sites). The physical characteristics of the sites have been previously reported (Hicks \& McCaughan 1997). The fish populations of these streams were dominated by longfinned eels (Anguilla dieffenbachii), though shortfinned eels ( $A$. australis) were also abundant at pasture sites (Hicks \& McCaughan 1997). Banded kokopu (Galaxias fasciatus) occurred at forested sites, and Cran's and redfinned bullies (Gobiomorphus basalis and $G$. huttoni) were found at exotic forest and pasture sites. Common smelt (Retropinna retropinna) occurred at one pasture site only. The freshwater crayfish (Paranephrops planifrons) was common at all sites.

\section{MATERIALS AND METHODS}

The majority of samples were collected in January and early February 1993, and from one site in January 1994. Some additional invertebrates samples used to make up a core group at each site 
were collected late March and early April 1993. Supplementary watercress (Rorippa nasturtiumaquaticum), algal, and molluscan samples were collected from site PW2 in early March 1995 by S. E. Bunn (Griffith University, Queensland, Australia). On collection, samples were stored at $0^{\circ} \mathrm{C}$ in crushed ice for transport to the laboratory within $3 \mathrm{~h}$. Fish guts were removed and preserved in $10 \%$ formalin before analysis. White muscle was cut from the fish and oven-dried to a constant weight at $40^{\circ} \mathrm{C}$, which usually required $24 \mathrm{~h}$. Muscle from the tails of crayfish was removed from the exoskeleton and oven-dried for $24 \mathrm{~h}$ at $40^{\circ} \mathrm{C}$. Other invertebrates and conditioned leaf litter were similarly dried whole. Guts were not removed from the invertebrates. After drying, leaf material from woody plants was ground in a ball mill to a fine, homogeneous powder. Algal and animal tissues were ground under liquid $\mathrm{N}_{2}$ with a mortar and pestle. The molluscan scrapers Latia and Potamopyrgus were ground whole, with their shells, except for the 1995 sample in which some were first acid-washed.

Among the invertebrates, the largest sized individuals were selected for stable isotope analysis. Total lengths of fish analysed were $95-242 \mathrm{~mm}$ (mean $166 \mathrm{~mm}, N=8$ ) for banded kokopu, 54-92 mm (mean $71 \mathrm{~mm}, N=17$ ) for Cran's bullies, 178$987 \mathrm{~mm}$ (mean $411 \mathrm{~mm}, N=79$ ) for longfinned eels, and 109-498 mm (mean $288 \mathrm{~mm}, N=40$ ) for shortfinned eels. Fork length was $79-85 \mathrm{~mm}$ (mean $83 \mathrm{~mm}, N=5$ ) for common smelt. The size range of crayfish sampled for stable isotopes was 5.1$36.3 \mathrm{~mm}$ OCL (orbit-carapace length; mean 19.4 $\mathrm{mm}, N=68$ ). These size data were pooled across all land-use types.

\section{Isotopic fractionation}

Water samples were analysed for dissolved inorganic $\mathrm{C}$ (DIC) concentration and $\delta^{13} \mathrm{C}$ using the methods of McCabe (1985). Measurements of isotopic ratios were made using a VG Micromass 602E mass spectrometer with double ion-collection and inlet systems, equipped for rapid switching between standard and samples for high accuracy and precision. For measuring biotic samples, where lower accuracy and precision was acceptable, a Europa Scientific Tracermass mass spectrometer with a single ion-collector and inlet system was used. Small subsamples (3-6 mg) of dried, ground material were weighed with a 5-place balance, and oxidised at high temperature in the furnace of a Carlo Erba CHNO analyser gas chromatograph. The resultant $\mathrm{CO}_{2}$ or $\mathrm{N}_{2}$ stream was then analysed with the Tracermass to a precision of c. $0.1 \%$ for ${ }^{13} \mathrm{C}$ and $0.3 \%$ for ${ }^{15} \mathrm{~N}$. Correction for drift was made automatically by the Tracermass from a reference sample of known fractionation measured every 40 or so samples.

The ratios of ${ }^{13} \mathrm{C} /{ }^{12} \mathrm{C}$ and ${ }^{15} \mathrm{~N} /{ }^{14} \mathrm{~N}$ were expressed as relative difference per mil (\%o) using the equation:

$$
\delta X=\left[\frac{R_{\text {sample }}}{R_{\text {standard }}}-1\right] \times 1000
$$

where $X={ }^{13} \mathrm{C}$ or ${ }^{15} \mathrm{~N}$, and $R={ }^{13} \mathrm{C} /{ }^{12} \mathrm{C}$ or ${ }^{15} \mathrm{~N} /{ }^{14} \mathrm{~N}$. The ratio of ${ }^{13} \mathrm{C}$ to ${ }^{12} \mathrm{C}$ was compared to the $\mathrm{PDB}$ standard, for which $R$ standard $=1.1237$ atom $\%{ }^{13} \mathrm{C}$ (Craig 1957). For ${ }^{15} \mathrm{~N} /{ }^{14} \mathrm{~N}, \mathrm{~N}_{2}$ in air was used as the standard, and $R_{\text {standard }}=0.3663$ atom $\%{ }^{15} \mathrm{~N}$ (Mariotti 1983).

\section{Data analysis}

To find group means for $\delta^{13} \mathrm{C}$ and $\delta^{15} \mathrm{~N}$, the foodweb components were assigned a priori to the various consumer groups. Assignation to consumer groups was made on the basis of previous studies (Rounick et al. 1982; Winterbourn 1982; Winterbourn et al. 1984; Linklater 1991; Quinn et al. 1992; Linklater \& Winterbourn 1993), except for Ichthybotus, which was classified as a predator on the basis of its large, tusk-like mandibles. Values of $\delta^{13} \mathrm{C}$ and $\delta^{15} \mathrm{~N}$ were compared among land-use types using Kruskal-Wallis nonparametric one-way analysis of variance, which reduces to a MannWhitney $U$ test for two samples, and Tukey's multiple comparison test (Zar 1984; Wilkinson et al. 1994).

\section{RESULTS}

\section{Stable isotope ratios}

Leaf litter was the most ${ }^{15} \mathrm{~N}$-depleted food web component in all land-use types (Table 1). Dual isotope plots of $\delta^{13} \mathrm{C}$ and $\delta^{15} \mathrm{~N}$ showed that leaf litter was the primary $\mathrm{C}$ source of food webs in forest streams (Fig. 1). Epilithic diatoms were an insignificant food source in forest streams, as shown by their ${ }^{15} \mathrm{~N}$-enrichment and ${ }^{13} \mathrm{C}$-depletion compared to other food-web components. However, in pasture streams the distinction between leaf litter and epilithic diatoms as a $\mathrm{C}$ source was less clear (Fig. 1). The wide variation in $\delta^{13} \mathrm{C}$ suggests that although diatoms were probably a food source in some pasture streams, in other pasture streams the 
sampled diatoms were too enriched in ${ }^{13} \mathrm{C}$ to be a significant $\mathrm{C}$ source. Filamentous green algae were found only in pasture streams, and also showed a considerable range of $\delta^{13} \mathrm{C}$ values, but were on average too enriched in ${ }^{15} \mathrm{~N}$ to be a food of the nonpredatory invertebrates. However, crayfish in pasture streams appeared likely to have consumed filamentous algae (Fig. 1). The $\delta^{13} \mathrm{C}$ and ${ }^{15} \mathrm{~N}$ values of the single moss sample from a pasture stream showed that it was unlikely to have been a significant $\mathrm{C}$ source.

Fish were the top aquatic consumers because they had the highest mean $\delta^{15} \mathrm{~N}$ values in all land uses (Fig. 1). The mean $\delta^{13} \mathrm{C}$ of fish (all species combined) were very similar among land-use types, despite the differences in $\delta^{13} \mathrm{C}$ of the leaf litter in each land-use type. The range of $\delta^{13} \mathrm{C}$ in all 129 fish measured was -22.9 to $-28.4 \%$. Crayfish were

Table 1 Mean $\delta^{13} \mathrm{C}$ and $\delta^{15} \mathrm{~N}$ values of putative carbon (C) sources and a priori consumers in streams in native forest (NF), exotic forest (EF), and pasture (PA) in the Waikato region, New Zealand, in summer 1993.

\begin{tabular}{|c|c|c|c|c|c|c|}
\hline \multirow[b]{2}{*}{ Consumer group } & \multirow[b]{2}{*}{ Taxon } & \multirow{2}{*}{$\begin{array}{c}\text { Land- } \\
\text { use } \\
\text { type }\end{array}$} & \multicolumn{2}{|c|}{$\delta^{13} \mathrm{C}(\%)$} & \multicolumn{2}{|c|}{$\delta^{15} \mathrm{~N}(\%)$} \\
\hline & & & $N$ & Mean & $N$ & Mean \\
\hline Conditioned leaf litter & & $\begin{array}{l}\text { NF } \\
\text { EF } \\
\text { PA }\end{array}$ & $\begin{array}{r}9 \\
12 \\
14\end{array}$ & $\begin{array}{l}-29.7 \\
-29.1 \\
-27.2\end{array}$ & $\begin{array}{l}18 \\
24 \\
28\end{array}$ & $\begin{array}{r}-1.4 \\
-0.2 \\
2.4\end{array}$ \\
\hline $\begin{array}{l}\text { Primary producers } \\
\text { Epilithic diatoms }\end{array}$ & & $\begin{array}{l}\text { NF } \\
\text { EF } \\
\text { PA }\end{array}$ & $\begin{array}{l}3 \\
4 \\
4\end{array}$ & $\begin{array}{l}-32.3 \\
-31.6 \\
-24.6\end{array}$ & $\begin{array}{l}3 \\
4 \\
4\end{array}$ & $\begin{array}{r}10.1 \\
7.4 \\
3.8\end{array}$ \\
\hline Filamentous green alga & Cladophora & PA & 10 & -26.3 & 10 & 6.4 \\
\hline Filamentous green alga & Spirogyra & $\mathrm{PA}$ & 3 & -20.3 & 3 & 1.9 \\
\hline Moss & & PA & 1 & -33.0 & 1 & 6.9 \\
\hline Filamentous red alga & Batrachospermum & $\mathrm{EF}$ & 1 & -40.1 & & \\
\hline $\begin{array}{l}\text { Non-predatory invertel } \\
\text { Oligochaete }\end{array}$ & tes: herbivores and detr & $\begin{array}{l}\text { EF } \\
\text { PA }\end{array}$ & $\begin{array}{l}2 \\
4\end{array}$ & $\begin{array}{l}-26.1 \\
-26.2\end{array}$ & $\begin{array}{l}2 \\
4\end{array}$ & $\begin{array}{l}2.9 \\
4.3\end{array}$ \\
\hline Amphipod & Paracalliope fluviatilis & $\mathrm{EF}$ & 1 & -27.2 & 1 & -0.5 \\
\hline Mayfly & Coloburiscus & $\begin{array}{l}\text { NF } \\
\text { EF } \\
\text { PA }\end{array}$ & $\begin{array}{r}9 \\
13 \\
4\end{array}$ & $\begin{array}{l}-26.9 \\
-27.3 \\
-26.2\end{array}$ & $\begin{array}{r}9 \\
13 \\
3\end{array}$ & $\begin{array}{l}3.2 \\
4.2 \\
5.0\end{array}$ \\
\hline Mayfly & Deleatidium & $\begin{array}{l}\mathrm{NF} \\
\mathrm{EF} \\
\mathrm{PA}\end{array}$ & $\begin{array}{l}3 \\
4 \\
4\end{array}$ & $\begin{array}{l}-29.1 \\
-29.8 \\
-27.6\end{array}$ & $\begin{array}{l}2 \\
3 \\
4\end{array}$ & $\begin{array}{l}1.6 \\
4.8 \\
4.4\end{array}$ \\
\hline Mayfly & Nesameletus & $\begin{array}{l}\mathrm{NF} \\
\mathrm{EF} \\
\mathrm{PA}\end{array}$ & $\begin{array}{l}5 \\
6 \\
9\end{array}$ & $\begin{array}{l}-32.7 \\
-33.3 \\
-25.7\end{array}$ & $\begin{array}{l}5 \\
5 \\
9\end{array}$ & $\begin{array}{l}3.0 \\
5.9 \\
5.0\end{array}$ \\
\hline Mayfly & Siphlaenigma & $\mathrm{EF}$ & 1 & -25.6 & 1 & 3.7 \\
\hline Mayfly & Zephlebia & $\begin{array}{l}\mathrm{NF} \\
\mathrm{EF} \\
\mathrm{PA}\end{array}$ & $\begin{array}{l}3 \\
7 \\
1\end{array}$ & $\begin{array}{l}-27.0 \\
-26.7 \\
-28.7\end{array}$ & $\begin{array}{l}3 \\
7 \\
1\end{array}$ & $\begin{array}{l}2.0 \\
4.0 \\
4.9\end{array}$ \\
\hline Net-spinning caddis & Hydropsychidae & $\begin{array}{l}\mathrm{NF} \\
\mathrm{EF} \\
\mathrm{PA}\end{array}$ & $\begin{array}{l}3 \\
4 \\
1\end{array}$ & $\begin{array}{l}-27.1 \\
-27.0 \\
-25.9\end{array}$ & $\begin{array}{l}3 \\
4\end{array}$ & $\begin{array}{l}1.8 \\
5.8\end{array}$ \\
\hline Cased caddis & Pycnocentria evecta & PA & 1 & -27.7 & 1 & 3.9 \\
\hline Non-biting midge & Chironomid & PA & 1 & -29.0 & & \\
\hline Pulmonate mollusc & Latia & $\begin{array}{l}\mathrm{NF} \\
\mathrm{EF} \\
\mathrm{PA}\end{array}$ & $\begin{array}{l}1 \\
8 \\
1\end{array}$ & $\begin{array}{l}-23.4 \\
-24.1 \\
-23.4\end{array}$ & $\begin{array}{l}1 \\
8 \\
1\end{array}$ & $\begin{array}{l}1.9 \\
7.9 \\
5.8\end{array}$ \\
\hline Gastopod mollusc & Potamopyrgus & $\begin{array}{l}\mathrm{NF} \\
\mathrm{EF} \\
\mathrm{PA}\end{array}$ & $\begin{array}{r}3 \\
3 \\
13 \\
\end{array}$ & $\begin{array}{l}-15.9 \\
-16.1 \\
-18.4\end{array}$ & $\begin{array}{r}3 \\
3 \\
13 \\
\end{array}$ & $\begin{array}{l}4.3 \\
5.4 \\
4.5\end{array}$ \\
\hline
\end{tabular}


always more enriched in ${ }^{13} \mathrm{C}$ than fish, but were less enriched in ${ }^{15} \mathrm{~N}$ (Fig. 1), suggesting that they ate primarily invertebrates, but that they probably also ate a variety of other foods. OCL explained $<6 \%$ of the variability in $\delta^{13} \mathrm{C}$ and $\delta^{15} \mathrm{~N}$. The increase in $\delta^{13} \mathrm{C}$ between leaf litter and fish was greater in forest sites than in pasture, and was $4.7 \%$ 。 in native forest $(-29.7$ to $-25.0 \%$ ), $4.0 \%$ in exotic forest $(-29.1$ to $-25.1 \%$ ), and $2.0 \%$ in pasture $(-27.3$ to $-25.3 \%)$. The average increase in $\delta^{13} \mathrm{C}$ per trophic step across the three steps between leaf litter, non-predatory invertebrates, predatory invertebrates, and fish was $1.6 \%$ in native forest, $1.3 \%$ in exotic forest, and $0.6 \%$ pasture.

The difference in $\delta^{15} \mathrm{~N}$ between predatory and non-predatory invertebrates other than crayfish suggests some degree of omnivory, or incorrect $a$ priori classification to consumer groups. The increase in $\delta^{15} \mathrm{~N}$ between leaf litter and fish was similar in all land-use types. The increases were $7.5 \%$ in native forest $(-1.3$ to $6.2 \%$ ), $8.4 \%$ in exotic forest $(-0.2$ to $8.2 \%)$, and $7.0 \%$ in pasture $(2.4$ to $9.4 \%$ ). The average increase in $\delta^{15} \mathrm{~N}$ per trophic step across the three steps between leaf litter, nonpredatory invertebrates, predatory invertebrates, and fish was $2.5 \%$ in native forest, $2.8 \%$ in exotic forest, and $2.3 \%$ pasture.

Conditioned leaf litter and epilithic diatoms were more ${ }^{13} \mathrm{C}$-enriched at pasture sites than at forested sites (Table 1,2). This trend was also shown by the collector-browsers Deleatidium and Nesameletus, and the net-spinning caddises of the

Table 1 (continued).

\begin{tabular}{|c|c|c|c|c|c|c|}
\hline \multirow[b]{2}{*}{ Consumer group } & \multirow[b]{2}{*}{ Taxon } & \multirow{2}{*}{$\begin{array}{l}\text { Land- } \\
\text { use } \\
\text { type }\end{array}$} & \multicolumn{2}{|c|}{$\delta^{13} \mathrm{C}(\%)$} & \multicolumn{2}{|c|}{$\delta^{15} \mathrm{~N}(\%)$} \\
\hline & & & $N$ & Mean & $N$ & Mean \\
\hline \multicolumn{7}{|c|}{ Predatory invertebrates: first-level carnivores } \\
\hline Mayfly & Ameletopsis & $\begin{array}{l}\mathrm{NF} \\
\mathrm{EF}\end{array}$ & $\begin{array}{l}4 \\
2\end{array}$ & $\begin{array}{l}-27.7 \\
-26.7\end{array}$ & $\begin{array}{l}4 \\
2\end{array}$ & $\begin{array}{l}4.1 \\
5.3\end{array}$ \\
\hline Burrowing mayfly & Ichthybotus & $\begin{array}{l}\mathrm{NF} \\
\mathrm{EF}\end{array}$ & $\begin{array}{l}2 \\
4\end{array}$ & $\begin{array}{l}-26.3 \\
-26.6\end{array}$ & $\begin{array}{l}2 \\
4\end{array}$ & $\begin{array}{l}3.7 \\
4.8\end{array}$ \\
\hline Dragonfly & Antipodochlora & $\begin{array}{l}\mathrm{EF} \\
\mathrm{PA}\end{array}$ & $\begin{array}{l}2 \\
1\end{array}$ & $\begin{array}{l}-27.2 \\
-29.1\end{array}$ & $\begin{array}{l}2 \\
1\end{array}$ & $\begin{array}{l}4.5 \\
5.1\end{array}$ \\
\hline Dobsonfly & Archichauliodes & $\begin{array}{l}\text { NF } \\
\text { EF } \\
\text { PA }\end{array}$ & $\begin{array}{r}6 \\
13 \\
9\end{array}$ & $\begin{array}{l}-26.2 \\
-26.6 \\
-25.1\end{array}$ & $\begin{array}{r}5 \\
13 \\
8\end{array}$ & $\begin{array}{l}3.8 \\
4.8 \\
5.7\end{array}$ \\
\hline Free-living caddis & Hydrobiosis & $\begin{array}{l}\text { NF } \\
\text { PA }\end{array}$ & $\begin{array}{l}1 \\
8\end{array}$ & $\begin{array}{l}-27.4 \\
-26.1\end{array}$ & $\begin{array}{l}1 \\
7\end{array}$ & $\begin{array}{l}2.4 \\
5.9\end{array}$ \\
\hline Stonefly & Stenoperla & NF & 3 & -26.6 & 3 & 3.5 \\
\hline Flatworm & Turbellaria & $\begin{array}{l}\text { NF } \\
\text { EF } \\
\text { PA }\end{array}$ & $\begin{array}{l}1 \\
3 \\
2\end{array}$ & $\begin{array}{l}-26.6 \\
-26.8 \\
-26.2\end{array}$ & $\begin{array}{l}2 \\
2\end{array}$ & $\begin{array}{l}6.7 \\
7.4\end{array}$ \\
\hline \multicolumn{7}{|c|}{ Fish: second-level carnivores } \\
\hline Longfinned eel & Anguilla diffenbachii & $\begin{array}{l}\mathrm{NF} \\
\mathrm{EF} \\
\mathrm{PA}\end{array}$ & $\begin{array}{l}21 \\
28 \\
22\end{array}$ & $\begin{array}{l}-25.3 \\
-25.2 \\
-25.6\end{array}$ & $\begin{array}{l}21 \\
28 \\
22\end{array}$ & $\begin{array}{l}6.7 \\
8.4 \\
9.4\end{array}$ \\
\hline Shortfinned eel & Anguilla australis & $\begin{array}{l}\text { NF } \\
\text { EF } \\
\text { PA }\end{array}$ & $\begin{array}{r}6 \\
7 \\
21\end{array}$ & $\begin{array}{l}-24.4 \\
-23.9 \\
-25.2\end{array}$ & $\begin{array}{r}6 \\
7 \\
21\end{array}$ & $\begin{array}{l}6.1 \\
8.6 \\
8.9\end{array}$ \\
\hline Banded kokopu & Galaxias fasciatus & $\begin{array}{l}\mathrm{NF} \\
\mathrm{EF}\end{array}$ & $\begin{array}{l}7 \\
1\end{array}$ & $\begin{array}{l}-24.6 \\
-26.1\end{array}$ & $\begin{array}{l}7 \\
1\end{array}$ & $\begin{array}{l}5.0 \\
6.9\end{array}$ \\
\hline Cran's bully & Gobiomorphus basalis & $\begin{array}{l}\text { EF } \\
\text { PA }\end{array}$ & $\begin{array}{l}6 \\
4\end{array}$ & $\begin{array}{l}-25.6 \\
-24.7\end{array}$ & $\begin{array}{l}6 \\
4\end{array}$ & $\begin{array}{l}7.6 \\
8.6\end{array}$ \\
\hline Redfinned bully & Gobiomorphus huttoni & EF & 1 & -25.6 & 1 & 6.3 \\
\hline Common smelt & Retropinna retropinna & PA & 5 & -24.3 & 5 & 12.3 \\
\hline $\begin{array}{l}\text { Omnivores } \\
\text { Crayfish }\end{array}$ & Paranephrops planifrons & $\begin{array}{l}\text { NF } \\
\text { EF } \\
\mathrm{PA} \\
\end{array}$ & $\begin{array}{l}22 \\
23 \\
22 \\
\end{array}$ & $\begin{array}{l}-24.5 \\
-24.5 \\
-24.4 \\
\end{array}$ & $\begin{array}{l}22 \\
23 \\
22 \\
\end{array}$ & $\begin{array}{l}4.5 \\
6.2 \\
7.8 \\
\end{array}$ \\
\hline
\end{tabular}




\begin{tabular}{|ll|}
\hline O epilithic diatoms \\
leaf litter \\
non-predatory invertebrates \\
predatory invertebrates \\
fish \\
0 crayfish \\
$\Delta$ moss \\
$\square$ filamentous green algae \\
\hline
\end{tabular}

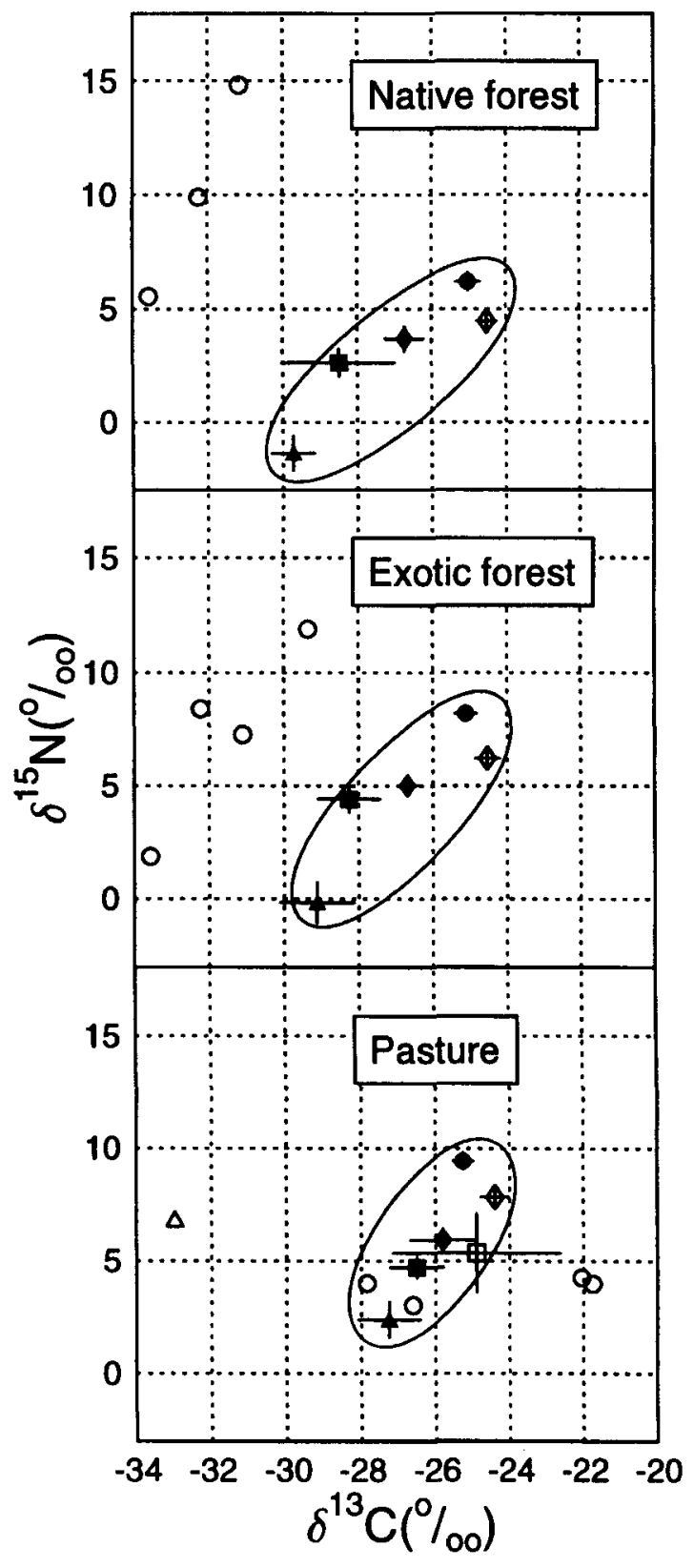

family Hydropsychidae. In forested streams, Nesameletus was by far the most ${ }^{13} \mathrm{C}$-depleted of any invertebrate. This suggests that primary food of Nesameletus might have been the similarly ${ }^{13} \mathrm{C}$ depleted epilithic diatoms, but the higher $\delta^{15} \mathrm{~N}$ values of the diatoms show that diatoms could not have been the sole food. Deleatidium, Zephlebia, Latia, and flatworms were not significantly different in $\delta^{13} \mathrm{C}$ or $\delta^{15} \mathrm{~N}$ among land-use types (Table 1,2).

Table 2 Probabilities $(P)$ for Kruskal-Wallis of significance of differences in $\delta^{13} \mathrm{C}$ and $\delta^{15} \mathrm{~N}$ among land-use types for trophic groups in forest and pasture streams in the Waikato region, New Zealand.

\begin{tabular}{|c|c|c|}
\hline \multirow[b]{2}{*}{ Trophic group } & \multicolumn{2}{|c|}{$P$} \\
\hline & $\delta^{13} \mathrm{C}$ & $\delta^{15} \mathrm{~N}$ \\
\hline Conditioned leaf litter & 0.001 & $<0.001$ \\
\hline Epilithic diatoms & 0.025 & 0.116 \\
\hline Coloburiscus & 0.027 & 0.009 \\
\hline Deleatidium & 0.192 & 0.105 \\
\hline Nesameletus & 0.003 & 0.104 \\
\hline Zephlebia & 0.220 & 0.095 \\
\hline Hydropsychidae & 0.032 & 0.034 \\
\hline Latia & 0.285 & 0.169 \\
\hline Potamopyrgus & 0.023 & 1.000 \\
\hline Archichauliodes & 0.002 & 0.003 \\
\hline Flatworms & 0.439 & 0.121 \\
\hline Longfinned eels & 0.539 & $<0.001$ \\
\hline Shortfinned eels & 0.007 & 0.001 \\
\hline Crayfish & 0.551 & $<0.001$ \\
\hline
\end{tabular}

Table 3 Dissolved inorganic carbon (DIC) in streams in exotic forest, native forest, and pasture in the Waikato region, New Zealand. ( $\mathrm{CL}=95 \%$ confidence limit.)

\begin{tabular}{lrrrr}
\hline & \multicolumn{3}{c}{ DIC (millimol litre ${ }^{-1}$ ) } \\
\cline { 3 - 5 } Land-use type & $N$ & Mean & Lower CL & Upper C \\
\hline DIC concentration & & & \\
Native forest & 5 & 0.21 & 0.15 & 0.27 \\
Exotic forest & 6 & 0.16 & 0.13 & 0.19 \\
Pasture & 8 & 0.22 & 0.21 & 0.24 \\
& & & \multicolumn{2}{c}{$\delta^{13} \mathrm{C}$}
\end{tabular}

Stable carbon isotopic composition of the DIC

\begin{tabular}{lllll} 
Native forest & 6 & -14.2 & -15.3 & -13.0 \\
Exotic forest & 6 & -13.0 & -15.5 & -10.5 \\
Pasture & 7 & -16.5 & -19.0 & -13.9 \\
\hline
\end{tabular}

Fig. 1 Mean fractionation of stable carbon (C) and nitrogen $(\mathrm{N})$ isotopes by presumed consumer categories in streams grouped by land-use type in forest and pasture in the Waikato region of New Zealand. Vertical and horizontal bars are $95 \%$ confidence intervals. Ellipse for each land use defines the main path of isotopic fractionation. 
However, Potamopyrgus was more negative in $\delta^{13} \mathrm{C}$ at pasture sites than at forested sites, reflecting the lower $\delta^{13} \mathrm{C}$ of DIC at pasture sites that was incorporated into the non-dietary $\mathrm{C}$ in its shell (Table $3 \mathrm{~B}$ ). The ${ }^{13} \mathrm{C}$-enrichment of Latia also showed contamination with non-dietary $\mathrm{C}$.

Archichauliodes, Ichthybotus, Stenoperla, and the flatworms (Turbellaria) were clearly predators, whereas Ameletopsis and Antipodochlora are more likely to be omnivores. The predator

Table 4 Variability of $\delta^{13} \mathrm{C}$ and $\delta^{15} \mathrm{~N}$ values of Cladophora and watercress at a pasture site (PW2) in late summer (9 March 1995; S. E. Bunn unpubl. data).

\begin{tabular}{llll}
\hline Autotroph & Habitat & $\delta^{13} \mathrm{C}$ & $\delta^{15} \mathrm{~N}$ \\
\hline Cladophora & pool & -22.7 & 3.42 \\
Cladophora & pool & -23.2 & 2.83 \\
Cladophora & pool & -23.6 & 2.89 \\
& & & \\
Cladophora & run & -27.3 & 3.14 \\
Cladophora & run & -27.4 & 2.20 \\
Cladophora & run & -29.7 & 2.57 \\
& & & \\
Watercress & & -27.8 & 4.01 \\
Watercress & & -28.3 & 5.02 \\
Watercress & & -28.6 & 4.53 \\
Watercress & & -28.9 & 5.52 \\
Watercress & & -29.3 & 5.67 \\
\hline
\end{tabular}

Archichauliodes had less negative $\delta^{13} \mathrm{C}$ and $\delta^{15} \mathrm{~N}$ values at pasture than at forest sites (Table 1,2). Fish were clearly second-level carnivores. Among fish and crayfish there was a strong trend of increasing $\delta^{15} \mathrm{~N}$ values from native forest to exotic forest to pasture (Table 1). Common smelt had much higher $\delta^{15} \mathrm{~N}$ than other fish at site PT2, probably reflecting their up-stream migration from the sea and lower river to their stream spawning sites.

The mean amount of DIC was greater in pasture than in exotic forest (Table 3A; Kruskal-Wallis $P=$ 0.018 ; Tukey multiple range test $P=0.007$ ). However, the $\delta^{13} \mathrm{C}$ of the DIC was not different among land-use types (Table 3B; Kruskal-Wallis $P$ $=0.068$ ), and ranged widely from -10.3 to $-19.5 \%$. Assuming that the DIC was the main source of C for aquatic photosynthesis, the mean shift in $\delta^{13} \mathrm{C}$ caused by photosynthesis in the epilithic diatoms was $18.1 \%$ at native forest sites $(-14.2$ decreased to $-32.2 \%), 18.6 \%$ at exotic forest sites $(-13.0$ decreased to $-31.6 \%$ ) , but only $8.1 \%$ at pasture sites $(-16.5$ decreased to $-24.6 \%)$. By visual examination it was found that all thin $(<0.5 \mathrm{~mm})$ epilithic films in this study were dominated by diatoms. Filamentous green algae at pasture sites had a very wide range of $\delta^{13} \mathrm{C}$ values $(-18.8$ to $-28.9 \%$ ). Batrachospermum, a filamentous red alga

Table 5 Occurrence of aquatic and terrestrial prey items in the guts of fish in streams in native and exotic forest, and in pasture, in the Waikato region, New Zealand.

\begin{tabular}{|c|c|c|c|c|}
\hline $\begin{array}{l}\text { Land-use } \\
\text { type }\end{array}$ & $\begin{array}{l}\text { Total no. } \\
\text { of fish } \\
\text { examined }\end{array}$ & $\begin{array}{c}\text { Total no. } \\
\text { of taxa }\end{array}$ & $\begin{array}{c}\% \\
\text { aquatic } \\
\text { taxa }\end{array}$ & $\begin{array}{c}\% \\
\text { terrestrial } \\
\text { taxa }\end{array}$ \\
\hline $\begin{array}{l}\text { Longfinned eels } \\
\text { Native forest } \\
\text { Exotic forest } \\
\text { Pasture }\end{array}$ & $\begin{array}{l}22 \\
28 \\
23\end{array}$ & $\begin{array}{l}32 \\
42 \\
31\end{array}$ & $\begin{array}{l}56 \\
62 \\
58\end{array}$ & $\begin{array}{l}44 \\
38 \\
42\end{array}$ \\
\hline $\begin{array}{l}\text { Shortfinned eels } \\
\text { Native forest } \\
\text { Exotic forest } \\
\text { Pasture }\end{array}$ & $\begin{array}{r}7 \\
7 \\
21\end{array}$ & $\begin{array}{r}7 \\
11 \\
27\end{array}$ & $\begin{array}{r}71 \\
100 \\
78\end{array}$ & $\begin{array}{r}29 \\
0 \\
22\end{array}$ \\
\hline $\begin{array}{l}\text { Banded kokopu } \\
\text { Native forest } \\
\text { Exotic forest }\end{array}$ & $\begin{array}{l}7 \\
1\end{array}$ & $\begin{array}{r}19 \\
1\end{array}$ & $\begin{array}{r}53 \\
100\end{array}$ & $\begin{array}{r}47 \\
0\end{array}$ \\
\hline $\begin{array}{l}\text { Cran's bully } \\
\text { Exotic forest } \\
\text { Pasture }\end{array}$ & $\begin{array}{l}6 \\
4\end{array}$ & $\begin{array}{l}9 \\
9\end{array}$ & $\begin{array}{l}100 \\
100\end{array}$ & $\begin{array}{l}0 \\
0\end{array}$ \\
\hline $\begin{array}{l}\text { Redfinned bully } \\
\text { Exotic forest }\end{array}$ & 1 & 5 & 100 & 0 \\
\hline $\begin{array}{l}\text { Common smelt } \\
\text { Pasture }\end{array}$ & 5 & 8 & 100 & 0 \\
\hline
\end{tabular}


that was found at one exotic forest site, had a very low $\delta^{13} \mathrm{C}$ value $(-40.1 \%$; Table 1$)$.

Localised differences in water velocity appeared to have affected the ${ }^{13} \mathrm{C}$ depletion of filamentous green algae, and might account for the wide range of $\delta^{13} \mathrm{C}$ values that were found. Cladophora and Spirogyra were the commonly occurring genera of filamentous green algae, and formed substantial accumulations in slower flowing microsites in the pasture streams in January and February 1993. The $\delta^{13} \mathrm{C}$ of Cladophora was considerably less negative in pools (mean $-23.2 \%$ ) than in runs (mean $-28.1 \%$; Table 4). Pools in similar sized Waikato streams had a mean velocity of $0.12 \mathrm{~m} \mathrm{~s}^{-1}(N=$ $95)$, but at the margins, where the greatest abundance of filamentous algae occurred, water velocities were close to zero. Runs had a mean velocity of $0.24 \mathrm{~m} \mathrm{~s}^{-1}(N=95$; B. J. Hicks unpubl. data). Mean $\delta^{15} \mathrm{~N}$ for filamentous algae was not different among pool and run habitats, and the mean for both habitats was $2.8 \%$ (95\% confidence interval $=0.4 \%, N=6$ ). Watercress was too ${ }^{13} \mathrm{C}$ depleted, and too ${ }^{15} \mathrm{~N}$-enriched to have contributed significantly to the food webs of pasture streams (Table 4).

The gastropod scrapers Latia and Potamopyrgus collected in 1993 and 1994 had low $\delta^{13} \mathrm{C}$ values because they were processed with their shells, so were contaminated with non-dietary $\mathrm{C}$. To test the effect of this contamination, the 1995 samples from PW2 were acid-washed to remove the $\mathrm{CaCO}_{3}$ in the shells. An acid-washed sample of Potamopyrgus had a $\delta^{13} \mathrm{C}$ of $-25.1 \%$, compared to $-20.1 \%$ for a sample that was not acid-washed. The $\delta^{15} \mathrm{~N}$ value was unaffected by acid washing; the acid-washed Potamopyrgus sample had a $\delta^{15} \mathrm{~N}$. of $5.0 \%$, compared to $4.7 \%$ for the sample that was not acidwashed (S. E. Bunn unpubl. data).

Table 6 Food items in fish guts in streams in forest and pasture in the Waikato region, New Zealand. Aquatic insects are larval or nymphal stages unless otherwise stated. Only items occurring in $\geq 10 \%$ of the guts examined are listed. (Origin: $\mathrm{t}=$ terrestrial; $\mathrm{a}=$ aquatic.)

\begin{tabular}{|c|c|c|c|c|c|c|c|c|}
\hline \multicolumn{3}{|c|}{ Native forest } & \multicolumn{3}{|c|}{ Exotic forest } & \multicolumn{3}{|c|}{ Pasture } \\
\hline Item & $\%$ & Origin & Item & $\%$ & Origin & Item & $\%$ & Origin \\
\hline \multicolumn{9}{|l|}{ Longfinned eels } \\
\hline Cicada & 36 & $\mathrm{t}$ & Zephlebia & 50 & a & Hydrobiosis & 70 & a \\
\hline Leptophlebiidae & 36 & a & Oligochaete & 29 & a & Potamopyrgus & 48 & a \\
\hline Crayfish & 32 & a & Harvestman & 25 & $\mathrm{t}$ & Harvestman & 35 & $\mathrm{t}$ \\
\hline Harvestman & 27 & $\mathrm{t}$ & Ichthybotus & 25 & $\mathbf{a}$ & Crayfish & 30 & $\mathbf{a}$ \\
\hline Spider & 23 & $\mathrm{t}$ & Crayfish & 25 & $\mathbf{a}$ & Leptophlebiidae & 26 & $\mathrm{a}$ \\
\hline Zephlebia & 18 & a & Millipede & 25 & $\mathrm{t}$ & Amphipod & 22 & a \\
\hline Deleatidium & 14 & a & Cicada & 21 & $\mathrm{t}$ & Aoteapsyche & 17 & a \\
\hline Gordian worm & 14 & a & Aoteapsyche & 18 & a & Brown beetle & 13 & $\mathrm{t}$ \\
\hline Green beetle & 14 & $\mathrm{t}$ & Caterpillar & 18 & $\mathrm{t}$ & Chironomid & 13 & a \\
\hline \multirow[t]{4}{*}{ Oligochaete } & 14 & $\mathbf{a}$ & Deleatidium & 18 & $\mathbf{a}$ & Deleatidium & 13 & a \\
\hline & & & Spider & 14 & $\mathrm{t}$ & & & \\
\hline & & & Ant & 11 & $t$ & & & \\
\hline & & & Hydrobiosis & 11 & $\mathbf{a}$ & & & \\
\hline \multicolumn{9}{|l|}{ Shortfinned eels } \\
\hline Leptophlebiidae & 71 & $\mathbf{a}$ & Zephlebia & 57 & a & Hydrobiosis & 52 & a \\
\hline Crayfish & 57 & $\mathbf{a}$ & Crayfish & 43 & $\mathbf{a}$ & Chironomidae & 33 & a \\
\hline Deleatidium & 29 & a & Ichthybotus & 29 & a & Leptophlebiidae & 24 & a \\
\hline Ant & 14 & $\mathrm{t}$ & Oligochaete & 29 & a & Oxyethira & 24 & a \\
\hline Beetle & 14 & $\mathrm{t}$ & Ameletopsis & 14 & a & Amphipod & 14 & a \\
\hline Polyplectropus & 14 & a & Amphipod & 14 & $\mathbf{a}$ & Cased caddis & 14 & $\mathbf{a}$ \\
\hline \multirow{7}{*}{ Zephlebia } & 14 & $\mathbf{a}$ & Archichauliodes & 14 & a & Harvestman & 14 & $\mathrm{t}$ \\
\hline & & & Ceratopogindae & 14 & a & Oligochaete & 14 & a \\
\hline & & & Coloburiscus & 14 & a & Potamopyrgus & 14 & $\mathbf{a}$ \\
\hline & & & Deleatidium & 14 & a & Caterpillar & 10 & $\mathrm{t}$ \\
\hline & & & Leptophlebiidae & 14 & $\mathbf{a}$ & Deleatidium & 10 & a \\
\hline & & & & & & Spider & 10 & $\mathrm{t}$ \\
\hline & & & & & & Tipulid & 10 & a \\
\hline
\end{tabular}




\section{Gut contents of fish}

Out of 132 fish guts examined, only two were completely empty. It was necessary to enumerate items in the whole gut, rather than just the stomach, as the hindgut of many fish was much fuller than the stomach. Most prey items were identifiable, though because of the advanced stage of digestion, some items could be recognised only by small fragments. For this reason volumetric and mass analyses were impractical. Aquatic prey were found in all fish with any food in their gut, but terrestrial prey were also important for longfinned eels in all land-use types, and for banded kokopu (Table 5).
Terrestrial prey had a lower percentage occurrence in the guts of shortfinned eels than in longfinned eels, and were not eaten at all by Cran's bully, common smelt, or the one redfinned bully that was found.

For longfinned eels in forested streams, cicadas (Amphisalta zelandica) were a common food item, as were the leptophlebiid mayfly nymphs including Zephlebia and Deleatidium, and crayfish (Table 6). In exotic forest streams, oligochaetes were a common food. In pasture streams, Hydrobiosis and Potamopyrgus were the most frequent food items for longfinned eels, whereas terrestrial harvestmen

Table 6 (continued).

\begin{tabular}{|c|c|c|c|c|c|c|c|c|}
\hline \multicolumn{3}{|c|}{ Native forest } & \multicolumn{3}{|c|}{ Exotic forest } & \multicolumn{3}{|c|}{ Pasture } \\
\hline Item & $\%$ & Origin & Item & $\%$ & Origin & Item & $\%$ & Origin \\
\hline \multicolumn{9}{|l|}{ Banded kokopu } \\
\hline Ant & 86 & $\mathrm{t}$ & Deleatidium & 100 & a & & & \\
\hline Cicada & 57 & $\mathrm{t}$ & & & & & & \\
\hline Zephlebia & 57 & a & & & & & & \\
\hline Harvestman & 43 & $\mathrm{t}$ & & & & & & \\
\hline Beetle & 29 & $\mathrm{t}$ & & & & & & \\
\hline Hydraenid adult & 29 & a & & & & & & \\
\hline Aoteapsyche & 14 & $\mathrm{a}$ & & & & & & \\
\hline Bully & 14 & a & & & & & & \\
\hline Caddisfly & 14 & a & & & & & & \\
\hline Centipede & 14 & $\mathrm{t}$ & & & & & & \\
\hline Deleatidium & 14 & $\mathbf{a}$ & & & & & & \\
\hline Elmid adult & 14 & a & & & & & & \\
\hline Green beetle & 14 & $\mathrm{t}$ & & & & & & \\
\hline Hydrobiosis & 14 & a & & & & & & \\
\hline Isopod & 14 & $\mathrm{t}$ & & & & & & \\
\hline Leptophlebiidae & 14 & $\mathbf{a}$ & & & & & & \\
\hline Millipede & 14 & $\mathrm{t}$ & & & & & & \\
\hline Potamoprygus & 14 & a & & & & & & \\
\hline Spider & 14 & $\mathrm{t}$ & & & & & & \\
\hline \multicolumn{9}{|l|}{ Cran's bullies } \\
\hline & & & Deleatidium & 33 & a & Chironomid & 100 & a \\
\hline & & & Leptophlebiidae & 33 & a & Oxyethira & 75 & a \\
\hline & & & Aoteapsyche & 17 & a & Candonocypris & so & $\mathrm{a}$ \\
\hline & & & Coloburiscus & 17 & $\mathrm{a}$ & Hydrobiosis & 50 & $\mathrm{a}$ \\
\hline & & & Conoesucidae & 17 & $\mathbf{a}$ & Austrosimulium & 25 & a \\
\hline & & & Ichthybotus & 17 & a & Deleatidium & 25 & a \\
\hline & & & Polycentropidae & 17 & a & Dipteran & 25 & $\mathrm{a}$ \\
\hline & & & Zephlebia & 17 & a & Empididae adult & 25 & a \\
\hline \multicolumn{9}{|l|}{ Common smelt } \\
\hline & & & & & & Oxyethira & 100 & a \\
\hline & & & & & & Chironomid & 60 & a \\
\hline & & & & & & Amphipod & 40 & a \\
\hline & & & & & & Caddisfly & 40 & a \\
\hline & & & & & & Elmid adult & 40 & a \\
\hline & & & & & & Deleatidium & 20 & a \\
\hline & & & & & & Hydrobiosis & 20 & a \\
\hline & & & & & & Leptophlebiidae & 20 & a \\
\hline
\end{tabular}


(Order Opiliones) were frequent dietary items in all land-use types. For shortfinned eels, harvestmen were the only important terrestrial prey in pasture streams (Table 6). Leptophlebiid mayflies and crayfish and were the most frequent prey items of shortfinned eels in forested streams, whereas Hydrobiosis and chironomid larvae were the most frequent prey items in pasture streams. Banded kokopu in native forest streams ate mainly ants (Family Formicidae), cicadas, Zephlebia, and harvestmen (Table 6). In Cran's bullies in exotic forest, Deleatidium and other leptophlebiid mayflies were the dominant dietary items, whereas in pasture, chironomids, the caddises Oxyethira and Hydrobiosis, and the ostracod Candonocypris were the principal foods. Common smelt ate mainly Oxyethira larvae, chironomids, amphipods, unidentified caddis larvae, and elmid beetles.

Among the less common items eaten by fish (i.e., $<10 \%$ occurrence) there was a wide variety of aquatic and terrestrial taxa. Aquatic taxa were more numerous $(N=43)$ than were terrestrial taxa $(N=$ 23). The intestinal parasite Eustrongilydes, or shagworm, was found in $86 \%$ of longfinned eels in native forest, $82 \%$ in exotic forest, and $74 \%$ in pasture. In shortfinned eels, shagworms occurred in $29 \%$ of eels in native forest, but not in the other land-use types. In banded kokopu, shagworms occurred in one out of the seven fish found in native forest, but not in the one fish found in exotic forest. There was no difference in $\delta^{13} \mathrm{C}$ between fish that had a large proportion of terrestrial taxa $(\geq 40 \%$ of food items) and those that had none in their stomachs when sampled (Mann-Whitney $U$ test; $P$ $=0.390$ ).

\section{DISCUSSION}

\section{Stable isotope ratios and food web analysis}

Food webs in these forested Waikato streams were based on allochthonous material. Epilithic diatoms appeared to be unimportant $\mathrm{C}$ sources for all invertebrates except for the ${ }^{13} \mathrm{C}$-depleted collectorbrowser Nesameletus. At some stream sites on the West Coast, South Island, Nesameletus was similarly ${ }^{13} \mathrm{C}$-depleted (Winterbourn et al. 1984). Patterns of isotopic fractionation among the foodweb components were consistent with the highly shaded nature of the forested sites, where photosynthesis was limited, epilithon biomass was low (Quinn et al. 1997a), and the riparian trees ensured a supply of allochthonous material.
Food webs in the open, pasture streams in this study were more ${ }^{13} \mathrm{C}$-enriched than were the shaded, forested streams, contrary to some previous New Zealand studies in which food webs at open sites were more ${ }^{13} \mathrm{C}$-depleted than at shaded sites (Rounick et al. 1982; Winterbourn et al. 1984). Food-web ${ }^{13} \mathrm{C}$-enrichment in Waikato streams seems to be attributable to the autotrophs. Epilithic diatoms were significantly more ${ }^{13} \mathrm{C}$-enriched at pasture sites than at forested sites (Table 1), in contrast to Wellington streams where stone surface scrapings at open sites were highly ${ }^{13} \mathrm{C}$-depleted ( -34.3 to $-35.8 \%$; Rounick \& Hicks 1985). Though ${ }^{13} \mathrm{C}$-enriched food webs occurred in Wellington streams, this enrichment at both open and shaded sites was based on the ${ }^{13} \mathrm{C}$-enrichment of fine particulate organic matter rather than epilithon (Rounick \& Hicks 1985). However, at open, pasture sites in the Waikato, the epilithic diatoms themselves were ${ }^{13} \mathrm{C}$-enriched compared to shaded, forest sites.

The wide range of $\delta^{13} \mathrm{C}$ and ${ }^{15} \mathrm{~N}$ values for the autotrophs in pasture streams made the extent of their contribution to food webs difficult to assess. The high rates of photosynthesis at these unshaded sites, combined with high temperatures (Quinn et al. 1997a), suggest that autotrophic production was responsible for the high eel biomass and productivity found by Hicks \& McCaughan (1997). The present study lacked a truly representative sampling of autotrophs that might have shown the quantitative contribution of primary producers to the pasture stream food webs. Also, microsite water velocity influenced the $\delta^{13} \mathrm{C}$ value of filamentous green algae in the 1995 sampling (Table 4). Water velocity was not recorded in the original 1993/94 sampling. The link between high rates of photosynthesis, low water velocities, and ${ }^{13} \mathrm{C}$-enrichment of aquatic autotrophs requires further investigation.

The dual isotope plot suggests that allochthonous material also contributed to the food webs in pasture streams (Fig. 1). The ${ }^{13} \mathrm{C}$ enrichment of conditioned leaf litter in pasture streams compared to forested streams (Table l) may have been caused by diatoms growing on submerged leaf surfaces. In pasture streams, the invertebrates Deleatidium, Nesameletus, and the hydropsychid caddises also showed ${ }^{13} \mathrm{C}$-enrichment, consistent the $\delta^{13} \mathrm{C}$ of the potential foods epilithic diatoms and FPOM derived from conditioned leaf litter. The ${ }^{13} \mathrm{C}$-enrichment of Archichauliodes suggested that it preyed primarily on some or all of these invertebrate taxa. 
Filamentous green algae appear to have been unavailable to invertebrates other than Potamopyrgus and crayfish; Bunn et al. (1997) similarly concluded that Spirogyra in a tropical stream had limited availability to invertebrate consumers. Watercress was also not a significant $C$ source in the pasture streams in which it occurred.

Fish in the Waikato had similar $\delta^{13} \mathrm{C}$ values in all land-use types (means -23.9 to $-25.6 \%$ ). This homogeneity may have resulted partly from the relatively large sample size $(N=129)$ in this study compared to previous studies. Fish in streams in the Wellington region had $\delta^{13} \mathrm{C}$ values between -19.5 and $-24.9 \%$ in a mixture of open and shaded sites (Rounick \& Hicks 1985). In streams under native forest on the West Coast of New Zealand, banded kokopu had $\delta^{13} \mathrm{C}$ values between -22 and $-25 \%$ (Main \& Lyon 1988).

Terrestrial taxa were significant in the diet of longfinned eels and banded kokopu in the Waikato, but the diets of shortfinned eels, Cran's bullies, and common smelt were dominated by aquatic taxa (Table 5). Main \& Lyon (1988) also reported that banded kokopu ate terrestrial prey. In the Waikato, fish feeding to a large extent $(\geq 40 \%)$ on terrestrial prey could not be distinguished isotopically from fish that ate exclusively aquatic prey. Terrestrial invertebrates as a $\mathrm{C}$ source might have confused the food web analysis, particularly since the isotopic ratios of terrestrial taxa were not measured in this study. Main \& Lyon found that the $\delta^{13} \mathrm{C}$ of terrestrial invertebrates ranged from -21 to $-28 \%$, with most values close to $-25 \%$. Another New Zealand study found that the $\delta^{13} \mathrm{C}$ for terrestrial invertebrates was $-24.4 \pm 1.4 \%$ o (mean $\pm 95 \%$ confidence interval; $N=10$ : McDowall et al. 1996). Without corresponding $\delta^{15} \mathrm{~N}$ values, these values cannot be distinguished from those of aquatic invertebrates.

Potamopyrgus appears to have eaten filamentous green algae. The 1995 mean $\delta^{13} \mathrm{C}$ of filamentous green algae in runs $(-28.1 \%)$ and its mean $\delta^{15} \mathrm{~N}(2.8 \%)$ suggest that it could have been a food for Potamopyrgus (acid-washed $\delta^{13} \mathrm{C}=$ $-25.1 \%$ and $\delta^{15} \mathrm{~N}=5.0 \%$ ). Further sampling is required to improve our knowledge of the relationship between molluscs and filamentous algae. The contamination of the Potamopyrgus samples by non-dietary C (e.g., Tanaka et al. 1986) has been confirmed in this study, and should be avoided in future.

Crayfish in Waikato streams appear from their $\delta^{13} \mathrm{C}$ and $\delta^{15} \mathrm{~N}$ values to be primarily predators, deriving most of their $\mathrm{C}$ from invertebrates. Though detritivory has been demonstrated in New Zealand crayfish (Parkyn et al. 1997), assimilation rates of plant material are likely to be low. In streams in Missouri, United States, the crayfish Orconectes assimilated only $14 \%$ of its detrital food compared to $92 \%$ of invertebrate food. These crayfish also ate filamentous algae, with an assimilation efficiency of $39 \%$ (Whitledge 1996). The assimilation efficiency of Paranephrops zealandicus for fresh and decayed oxygen weed (Elodea canadensis) averaged $21 \%$ (Musgrove 1988). Crayfish in the present study (mean $\delta^{13} \mathrm{C}$ -24.4 to $-24.5 \%$ ) were the most ${ }^{13} \mathrm{C}$-enriched of any consumer except for the gastropod scrapers, whose analyses were contaminated with non-dietary carbonates. Main \& Lyon (1988) also found that $P$. planifrons was the most highly ${ }^{13} \mathrm{C}$-enriched invertebrate $(-24.6 \%)$ in streams in South Westland, New Zealand. One explanation for the ${ }^{13} \mathrm{C}$-enrichment is that food in the crayfish gut might be assimilated by micro-organisms, with subsequent assimilation of these micro-organisms by the crayfish. Cellulase activity, which is normally absent from higher eukaryote organisms, has been detected in the gut of $P$. zealandicus (Musgrove 1988). This activity was associated with bacteria in the gut, but the extent of the contribution to crayfish nutrition by these micro-organisms was not established, and thus the expected isotopic enrichment is unknown. Filamentous green algae are a possible food source of crayfish in pasture streams in the Waikato, as the fractionation of $\mathrm{C}$ and $\mathrm{N}$ isotopes is in the right direction, and of about the right magnitude. In forested streams, where filamentous algae were generally absent, the $\delta^{13} \mathrm{C}$ enrichment of crayfish suggests that their predominant food was invertebrates.

Analyses of $\delta^{15} \mathrm{~N}$ augmented the $\delta^{13} \mathrm{C}$ analyses in this study, providing a second dimension that was useful for resolving trophic links. The use of both $\mathrm{C}$ and $\mathrm{N}$ isotopes overcame some of the criticisms recently aimed at stable $\mathrm{C}$ isotope studies by France (1995a; 1996a,b,c). There was a progressive enrichment in $\delta^{15} \mathrm{~N}$ in equivalent trophic levels between native forest and exotic forest, and between exotic forest and pasture. Invertebrates, eels, and crayfish in pasture streams were 2-3\% greater in $\delta^{15} \mathrm{~N}$ than they were in native forest streams (Table 1). Contributions of ruminant excreta or nitrogenous fertilisers to ground water might have caused the ${ }^{15} \mathrm{~N}$-enrichment of pasture streams. The exotic forest sites were in pasture until c. 15 years ago, which might account for their intermediate 
${ }^{15} \mathrm{~N}$-enrichment. The difference in $\delta^{15} \mathrm{~N}$ values between leaf litter and top consumers in this study (7.0-8.4\%) was similar to forested streams in the Pacific northwest of the United States (Fry 1991), though top consumers were considerably more enriched in ${ }^{13} \mathrm{C}$ in the United States' studies. The average size of trophic steps was $2-3 \%$ for $\delta^{15} \mathrm{~N}$, and $0.7-1.6 \%$ for $\delta^{13} \mathrm{C}$, close to expected values (Rounick \& Hicks 1985; Peterson \& Fry 1987; Handley \& Raven 1992). The $\delta^{15} \mathrm{~N}$ of the migratory common smelt $(12.3 \%$ ) was twice that of any other fish species, possibly reflecting consumption of ${ }^{15} \mathrm{~N}$-enriched estuarine or marine plankton (Peterson \& Howarth 1987).

\section{Variability of autotrophic $\delta^{13} \mathrm{C}$}

Variability in DIC did not appear to account for the variable $\delta^{13} \mathrm{C}$ of the autotrophs in this study. DIC $\delta^{13} \mathrm{C}$ means $(-13.0$ to $-16.5 \%$ ) were similar in all land uses, and were also similar to the range previously reported in New Zealand streams (-11.1 to $-15.5 \%$; Rounick et al. 1982; Rounick \& Hicks 1985). In forested Waikato streams, epilithic diatoms (mean $\delta^{13} \mathrm{C} \mathrm{c}$. $-32 \%$ ) were $18-19 \%$ more negative than the DIC, similar to predicted ${ }^{13} \mathrm{C}$ depletion by photosynthesis. At pasture sites, assuming that DIC was the C source for photosynthesis, epilithic diatoms were only c. $8 \%$ more negative than the DIC. ${ }^{13} \mathrm{C}$-enriched periphyton have been found at other stream sites in New Zealand; $\delta^{13} \mathrm{C}$ values of -10 to $-15 \%$ were found at open sites in the Styx River (Lester et al. 1995). Filamentous algae from open sites in the Manganuiateao River, central North Island, also had ${ }^{13} \mathrm{C}$-enriched values $\left(\delta^{13} \mathrm{C}-12.5\right.$ to $-16.8 \%$; Collier \& Lyon 1991).

One mechanism by which autotrophs can become ${ }^{13} \mathrm{C}$-enriched is through $\mathrm{C}$ limitation of photosynthesis, as competition for $\mathrm{C}$ substrate causes the usual discrimination against ${ }^{13} \mathrm{C}$ to break down. Low water velocity can cause increases in autotrophic $\delta^{13} \mathrm{C}$ through restricted mixing. Though substrate limitation of photosynthesis is unexpected in a well-mixed, temperate, lotic system, algae and cyanobacteria with ${ }^{13} \mathrm{C}$-enriched signatures are common in lentic environments (McCabe 1985; Bunn \& Boon 1993; Boon et al. 1994). Substrate limitation in lakes can result in phytoplankton with $\delta^{13} \mathrm{C}$ values close to $0 \%$ (McCabe 1985). In streams with high algal biomass, C limitation of photosynthesis might be sufficient to cause ${ }^{13} \mathrm{C}$ enrichment of the algae at low-velocity microsites.
Biomass of epilithon, including filamentous algae, was higher at pasture sites than at forested sites (Quinn et al. 1997a). The mean values at pasture sites in November $\left(3.6 \mathrm{~g} \mathrm{AFDM} \mathrm{m}^{-2}\right.$ ) were not high compared to previously recorded values in New Zealand streams, and to values recorded in unshaded channels at a pasture site in summer (maximum $12 \mathrm{~g} \mathrm{C} \mathrm{m}^{-2}$, =c. $24 \mathrm{~g} \mathrm{AFDM} \mathrm{m}^{-2}$; Quinn et al. 1997b). Cladophora-dominated algal communities can have biomasses in excess of 100 g AFDM m$~^{-2}$ (Biggs \& Price 1987). However, in midsummer at my sites, substantial abundance of filamentous green algae was observed. Algal accumulation depends on the length of period of flow recession as well as on nutrient status of the water (Biggs 1995). Maximum accumulation would be expected to occur around midsummer, when the samples for this study were taken, rather than in November when Quinn et al. (1997a) sampled.

Thus it is conceivable that in summer at microsites with high temperature, high accumulation of algal biomass, and low water velocity, the $\mathrm{C}$ substrate for photosynthesis in might become limiting in streams. Variable $\delta^{13} \mathrm{C}$ values in autotrophs could have resulted from sampling a variety of microhabitats with different water velocities. Alternatively, microbial respiration under low velocity conditions might have resulted in an undiscovered pool of dissolved inorganic carbon that was used by the autotrophs in Waikato streams.

\section{CONCLUSIONS}

Stable $\mathrm{C}$ and $\mathrm{N}$ isotope analyses combined with fish gut analyses have helped elucidate the structure of food webs in Waikato streams under different land uses. Within each of the three land uses, stream ecosystems behaved consistently. The food webs in forested streams followed the conventional smallstream, allochthonous-dominated model, whereas food webs in pasture streams had a mixture of allochthonous and ${ }^{13} \mathrm{C}$-enriched autochthonous inputs. For pasture streams, key areas for more detailed analysis are suggested. Questions remaining after this study include: (1) the cause of the variability in $\delta^{13} \mathrm{C}$ of the autotrophs, including seasonal variation; (2) the $\delta^{13} \mathrm{C}$ and $\delta^{15} \mathrm{~N}$ signatures of the contributing ground waters, and the extent to which the stream food web reflects these; (3) the role of dissolved organic carbon in stream food webs; and (4) the quantitative importance of terrestrial invertebrates. To improve our 
understanding of stream food webs through analysis of stable $\mathrm{C}$ and $\mathrm{N}$ isotopes, more attention to the $\mathrm{C}$ and $\mathrm{N}$ dynamics of epilithic films, and to their relation to groundwater inputs is necessary.

\section{ACKNOWLEDGMENTS}

I thank Lee Laboyrie, Barry Strong, and John Hicks for assistance with the field sampling. Lee Laboyrie also assisted with sample processing in the laboratory. Stable isotope ratios were determined by Anjana Rajendram of the Waikato Stable Isotope Unit, School of Science and Technology, University of Waikato. Chris Hendy of the Department of Chemistry, University of Waikato, carried out the DIC determinations. Stuart Bunn (Griffith University, Queensland, Australia) collected samples for further analysis of algae and Potamopyrgus. Critical comment was provided by Mike Winterbourn, University of Canterbury, and Bryce Cooper, John Quinn, and Kevin Collier of NIWA, Hamilton, and two anonymous referees. This project was entirely funded by a grant from the University of Waikato Research Committee.

\section{REFERENCES}

Biggs, B. 1995: Low flows and algal growth in streams. Water and atmosphere 3(1): 15-16.

Biggs, B. J. F.; Price, G. M. 1987: A survey of filamentous algae proliferations in New Zealand rivers. New Zealand journal of marine and freshwater research 21: 175-191.

Boon, P. I.; Bunn, S. E. 1994: Variation in the stable isotope composition of aquatic plants and their implications for food web analysis. Aquatic botany 48: 99-108.

Bunn, S. E.; Davies, P. M.; Kellaway, D. M. 1997: Contributions of sugar cane and invasive pasture grass to the aquatic food web of a tropical lowland stream. Marine and freshwater research 48: $173-179$.

Collier, K. J.; Lyon, G. L. 1991: Trophic pathways of blue duck (Hymenolaimus malacorhynchos) on Manganuiateao River: a stable carbon isotope study. New Zealand journal of marine and freshwater research 25: 181-186.

Craig, H. 1957: Isotopic standards for carbon and oxygen and correction factors for mass spectrometric analysis of carbon dioxide. Geochimica cosmochimica acta 12: 133-149.

Cummins, K. W.; Wilzbach, M. A.; Gates, D. M.; Perry, J. B.; Taliaferro, W. B. 1989: Shredders and riparian vegetation. Leaf litter that falls into streams influences communities of stream invertebrates. Bioscience 39: 24-30.

Ehleringer, J. R., Field, C. B.; Zhi-fang Lin; Chun-yen Kuo. 1986: Leaf carbon isotope and mineral composition in subtropical plants along an irradiance cline. Oecologia 70:520-526.
France, R. 1995a: Critical examination of stable isotope analysis as a means for tracing carbon pathways in stream ecosystems. Canadian journal of fisheries and aquatic sciences 52: 651-656.

France, R. L. 1995b: Source variability in $\delta^{15} \mathrm{~N}$ of autotrophs as a potential aid in measuring allochthony in freshwaters. Ecography 18: 318-320.

France, R. L. 1996a: Carbon-13 conundrums: limitations and cautions in the use of stable isotope analysis in stream ecological research. Canadian journal of fisheries and aquatic sciences 53: 1916-1919.

France, R. L. 1996b: Scope of use of stable carbon isotopes in discerning the incorporation forest detritus into aquatic food webs. Hydrobiologia 325: 219-222.

France, R. L. 1996c: Absence or masking of metabolic fractionations of ${ }^{13} \mathrm{C}$ in a freshwater benthic food web. Freshwater biology 36: 1-6.

Fry, B. 1991: Stable isotope diagrams of freshwater food webs. Ecology 72: 2293-2297.

Gregory, S. V.; Swanson, F. J.; McKee, W. A. 1991: An ecosystem perspective of riparian zones. Biosciences 41: 540-551.

Griffiths, H. 1991: Applications of stable isotope technology in physiological ecology. Functional ecology 5: 254-269.

Handley, L. L.; Raven, J. A. 1992: The use of natural abundance of nitrogen isotopes in plant physiology and ecology. Plant, cell, and environment 15: 965-985.

Hicks, B. J.; McCaughan, H. M. C. 1997: Land use, associated eel production, and abundance of fish and crayfish in streams in Waikato, New Zealand. New Zealand journal of marine and freshwater research 31: 635-650.

Lester, P. J.; Mitchell, S. F.; Scott, D.; Lyon, G. L. 1995 : Utilisation of willow leaves, grass and periphyton by stream macroinvertebrates: a study using stable carbon isotopes. Archiv für Hydrobiologie 133: 149-159.

Linklater, W. 1995: Breakdown and detritivore colonisation of leaves in three New Zealand streams. Hydrobiologia 306: 241-250.

Linklater, W.; Winterbourn, M. J. 1993: Life histories and production of two trichopteran shredders in New Zealand streams with different riparian vegetation. New Zealand journal of marine and freshwater research 27: 61-70.

Main, M. L.; Lyon, G. L. 1988: Contribution of terrestrial prey to the diet of banded kokopu (Galaxias fasciatus Gray) (Pisces: Galaxiidae) in South Westland, New Zealand. Vereinigung Internationale für Theoretische und Angewandte Limnologie Verhandlungen 23: 1785-1789. 
Mariotti, A. 1983: Atmospheric nitrogen is a reliable standard for natural ${ }^{15} \mathrm{~N}$ abundance measurements. Nature 303: 685-687.

McCabe, B. 1985: The dynamics of ${ }^{13} \mathrm{C}$ in several New Zealand lakes. Unpublished DPhil thesis, University of Waikato, Hamilton, New Zealand. $278 \mathrm{p}$.

McDowall, R. M.; Main, M. R.; West, D. W.; Lyon, G. L. 1996: Terrestrial and benthic foods in the diet of the shortjawed kokopu, Galaxias postvectis Clarke (Teleostei: Galaxiidae). New Zealand journal of marine and freshwater research 30 : 257-269.

Musgrove, R. J. 1988: Digestive ability of the freshwater crayfish Paranephrops zealandicus (White) (Parastacidae) and the role of microbial enzymes. Freshwater biology 20: 305-314.

O'Leary, M. H. 1988: Carbon isotopes in photosynthesis. Biosciences 38: 328-335.

Parkyn, S. M.; Rabeni, C. F.; Collier, K. J. 1997: Effects of crayfish (Paranephrops planifrons: Parastacidae) on in-stream processes and benthic faunas: a density manipulation experiment. New Zealand journal of marine and freshwater research 31: 685-692.

Peterson, B. J.; Fry, B. 1987: Stable isotopes in ecosystem studies. Annual review of ecology and systematics 18: 293-320.

Peterson, B. J.; Howarth, R. W. 1987: Sulfur, carbon, and nitrogen isotopes used to trace organic matter flow in the salt-marsh estuaries of Sapelo Island, Georgia. Limnology and oceanography 32: 1195-1213.

Quinn, J. M.; Cooper, A. B.; Davies-Colley, R. J.; Rutherford, J. C.; Williamson, R. B. $1997 \mathrm{a}$ : Landuse effects on habitat, water quality, periphyton, and benthic invertebrates in Waikato, New Zealand, hill-country streams. New Zealand journal of marine and freshwater research 31: 579-597.

Quinn, J. M.; Cooper, A. B.; Stroud, M. J; Burrell, G. P. 1997b: Shade effects on periphyton and invertebrates: an experiment in streamside channels. New Zealand journal of marine and freshwater research 31: 665-683.

Quinn, J. M.; Williamson, R. B.; Smith, R. K.; Vickers, M. L. 1992: Effects of riparian grazing and channelisation on streams in Southland, New Zealand. 2. Benthic invertebrates. New Zealand journal of marine and freshwater research 26: 259-273.

Rau, G. H. 1980: Carbon-13/carbon-12 variation in subalpine lake aquatic insects: food source implications. Canadian journal of fisheries and aquatic sciences 37: 742-745.
Rounick, J. S.; Hicks, B. J. 1985: The stable carbon isotope ratios of fish and their invertebrate prey in four New Zealand rivers. Freshwater biology 15: 207-214.

Rounick, J. S.; Winterbourn, M. J. 1983: The formation, structure and utilisation of stone surface organic layers in two New Zealand streams. Freshwater biology 13: 57-72.

Rounick, J. S.; Winterbourn, M. J. 1986: Stable carbon isotopes and carbon flow in ecosystems. Biosciences 36: 171-177.

Rounick, J. S.; Winterbourn, M. J.; Lyon, G. L. 1982: Differential utilisation of allochthonous and autochthonous inputs by aquatic invertebrates in some New Zealand streams: a stable carbon isotope study. Oikos 39: 191-198.

Schlesser, G. H. 1990: Investigations of the $\delta^{13} \mathrm{C}$ pattern in leaves of Fagus sylvatica L. Journal of experimental botany 41: 565-572.

Schlesser, G. H. 1992: $\delta^{13} \mathrm{C}$ pattern in a forest tree as an indicator of carbon transfer in trees. Ecology 73: 1922-1925.

Tanaka, N.; Monaghan, M. C.; Rye, D. M. 1986: Contribution of metabolic carbon to mollusc and barnacle shell carbonate. Nature 320: 520-523.

Vannote, R. L.; Minshall, G. W.; Cummins, K. W. 1980: The river continuum concept. Canadian journal of fisheries and aquatic sciences 37: 130-137.

Walcroft, A. S.; Silvester, W. B.; Whitehead, D.; Kelliher, F. M. 1997: Seasonal changes in stable carbon isotope ratios within annual rings of Pinus radiata reflect environmental regulation of growth processes. Australian journal of plant physiology 24: 57-68.

Whitledge, G. 1996: Trophic ecology of crayfish in the Jacks Fork River, Missouri. Unpublished MSc thesis, University of Missouri-Columbia, United States. $81 \mathrm{p}$.

Wilkinson, L.; Hill, M.; Howe, P.; Birkenbeuel, G.; Beck, J.; Liu, J. 1994: SYSTAT for DOS: advanced applications, version 6 edition. SYSTAT Inc., Evanston, Illinois. 902 p.

Winterbourn, M. J. 1982: The invertebrate fauna of a forest stream and its association with fine particulate matter. New Zealand journal of marine and freshwater research 16: 271-281.

Winterbourn, M. J.; Cowie, B., ; Rounick, J. S. 1984: Food resources and ingestion patterns of insects along a West Coast, South Island, river system. New Zealand journal of marine and freshwater research 18: 379-388.

Zar, J. H. 1984: Biostatistical analysis. Second edition. Englewood Cliffs, New Jersey, Prentice-Hall. $718 \mathrm{p}$. 